\title{
Effects of GABAA Receptors in Dorsal Hippocampus on Memory Retention of Cholestatic Rats
}

\section{Research Article}

Keywords:

Posted Date: May 4th, 2022

DOI: https://doi.org/10.21203/rs.3.rs-1068699/v2

License: (c) (1) This work is licensed under a Creative Commons Attribution 4.0 International License. Read Full License 


\section{Abstract}

Research Square has withdrawn this preprint due to text similarity concerns and do not wish this work to be cited as a reference.

\section{Full Text}

The authors have withdrawn this preprint from Research Square. 